\title{
Evaluation of Usability and Gameplay of Games on Mobile Platforms for Young People on Oncological Treatment
}

Guilherme Theisen Schneider - Universidade Feevale - gts@feevale.br

Débora Nice Ferrari Barbosa - Universidade Feevale - deboranice@feevale.br

Paulo Ricardo dos Santos - Universidade Feevale - paulo.s@feevale.br

Jorge Luís Victória Barbosa - Universidade do Vale do Rio do Sinos jbarbosa@unisinos.br

\begin{abstract}
This paper presents a method to evaluate usability and gameplay efficiency for educational games developed for children undergoing cancer treatment, as well as a case study involving the game "Corrida Gramatical". The methodology of this paper consists of the use of tablets by patients aged 10 to 15 years old to evaluate and quantify the usability and gameplay of the game, while the process is documented through non-participant observation, a System Usability Scale (SUS) questionnaire and a semi-structured interview. The proposed method has proved to be supportive in the evaluation of existing educational games, considering the participants of the research, as well as in the improvement of the game by analyzing the flaws identified in the game design. For future studies, we intend to change the inclusion criteria to select a larger group of patients and reaffirm the effectiveness of the proposed method.
\end{abstract}

Keywords. Digital Games. Usability. Gameplay. Game Design.

\section{Avaliação da Usabilidade e Jogabilidade de Jogos em Plataformas m Móveis para Jovens em Tratamento Oncológico}

Resumo. Este artigo apresenta um método para avaliar a eficiência da usabilidade e jogabilidade para jogos educacionais desenvolvidos para crianças em tratamento de câncer, assim como um estudo de caso envolvendo o jogo "Corrida Gramatical". A metodologia deste artigo consiste do uso de tablets por pacientes de idades entre 10 e 15 anos para avaliar e quantificar a usabilidade e jogabilidade do jogo, enquanto o processo é documentado através de uma observação não-participativa, um questionário de Escala de Usabilidade do Sistema (tradução de "System Usability Scale", SUS) e uma entrevista semiestruturada. O método proposto provou ser de auxílio na avaliação dos jogos digitais existentes, considerando os participantes da pesquisa, assim como na melhoria do jogo pela análise de falhas identificadas no design do jogo. Para estudos futuros, pretendemos alterar o critério de inclusão para selecionar um grupo maior de pacientes e reafirmar a efetividade do método proposto.

Palavras Chave. Jogos Digitais. Usabilidade. Jogabilidade. Design de jogos.

\section{Introduction}

Mobile devices, such as tablets and smartphones, as well as digital games, are current elements of interaction in our digital culture. In Digital Games studies, some researchers focus their work in a specific type of game called "serious games" (Raessens, 2009; Ritterffeld; Cody; Vorderer, 2009). Another area of serious games research connects education and health issues (Vianna and Barbosa, 2017; Dias et al., 2017; Mossmann et al, 2016). We have been developing mobile and game technologies with an appropriate way 
(Barbosa et al., 2014; Barbosa et al., 2011) to help students under cancer treatment to overcome learning problems, with emphasis on content for school reinforcement. The development of games must address appropriate gameplay according to the stages of the cancer treatment, such as chemotherapy stages, since depending on the specific disease and on the phase of treatment, the patient's level of debility may vary. In addition, the game must be combined with motivating and meaningful strategies, enabling learning and entertaining. The use of mobile devices and games with people undergoing medical treatment could be an effective resource for health education, especially for children and teenagers with chronic diseases, such as cancer. So it is necessary to use methods to evaluate usability (Shackel, 2009) and gameplay, which are essential elements in the context of games. A parallel between the two concepts can be drawn, where usability can be defined as "effectively achieving certain goals" and gameplay as "challenging goals" (Cybis, 2010).

Therefore, this paper proposes and applies a method of usability and gameplay evaluation in mobile devices for children and teenagers under oncological treatment. The evaluation proposal was applied as a case study in the educational game 2D called "Corrida Gramatical". The investigative method chosen is a qualitative research using a case study as a procedure, with evaluation instruments during and after the use of the game. The subjects of the research are patients aged 10 to 15 years old undergoing oncological treatment. All of them collaborated to the research "Learning with Mobility" developed with AMO (Associação de Assistência em Oncopediatria). The results show that it is possible to evaluate the usability and gameplay with the proposed method and that the methodology is suitable to support the development of mobile educational games considering the research scenario. Future studies will use a larger group to reaffirm the effectiveness of the proposed method.

This paper is organized in five sections. In section two, we discuss usability and gameplay. In section three the proposed method is exposed, indicating the evaluative methodology applied by us, the game "Corrida Gramatical", object of the research, and describing the subjects of the research. Section four describes the case studies, the subjects' experience during the application, and the responses and feedbacks for that purpose. Finally, in section five, the results and conclusions about the study are presented.

\section{Usability and Gameplay in digital games}

Usability (Shackel (2009; 1986); Preece et al. (1993)) is a key concept in the human computer interaction and emphasizes the concern in making systems that present ease of learning and use. For Nielsen (1995), usability is a quality attribute that evaluates the ease of use of an interface. Nielsen proposed ten heuristic methods for usability analysis in systems. For Shackel $(2009 ; 1986)$, the user builds perception about the product when he uses it. Moreno-Ger et al (2012), proposed a methodology for evaluation of usability in serious game called SeGUE. The methodology instruments contemplate tagging events in the recorded play sessions according to two dimensions: the system and the user. These data are analysed by a team of game programmers and designers, to better identify the game design, interface, interaction and the student involved.

The gameplay, according to Santos (2010, p. 131), "is the virtue that a game has to be easy and intuitive to play. The more quickly the player feels comfortable with the commands and its environment, the more playable it is". Gameplay influences the entertainment and, considering an educational game, influences the learning process (Diniz et al., 2017). Carvalho et al. (2015) proposes a framework for the analysis of educational games and to assist in their game design, enhancing gameplay elements that interfere in the game acceptance and learning. According to the authors, considering digital games, problems related to entertainment elements should also be detected and described in an 
evaluation, since they need to be corrected in the same way as usability problems. However, usability or entertainment problems are not individual issues. In fact, one influences the other, both approaches are connected, determining what we call gameplay. Considering serious game area, Moreno-Ger et al (2012), proposed a methodology for the evaluation of usability in serious game to identify the game design, interface, interaction and the student engaged in the perspective of usability. Carvalho et al. (2015) proposes a framework for the analysis of game design of educational games with focus on game acceptance and learning. In these studies, players with diverse ergonomic aspects, as health conditions, are not considered in the observation scenario.

As we observe the studies on usability and gameplay introduced in Preece et al. (1993), Shackel (1986; 2009), Diniz et al. (2017), Carvalho et al. (2015), Ribeiro, Fernandes and Garone (2013) and Cybis (2010) we can identify seven characteristics of usability and gameplay that should be analyzed in systems, including digital games. These characteristics are presented in their research as: 1) Efficacy; 2) Efficiency; 3) Security; 4) Utility; 5) Learning ability; 6) Storage capacity; 7) Satisfaction. The ideal usability seeks to perceive the system as a catalyst for the execution of tasks. Gameplay, on the other hand, seeks the perception of the game as a source of entertainment. Therefore, based on these studies, the need for proposals to analyze usability and gameplay in educational digital games is evident, understanding that the usability, currently more focused on systems, is also a fundamental element in digital games. The usability associated to the elements of gameplay guarantees a good acceptance of the game by the users and provides learning and entertaining experiences. In our research, besides attending different phases of the cancer treatment, gameplay must be suitable to emotional and physical aspects, since the wellness of patients can be variable. Although the game objective is teaching Portuguese grammar, at this point we have not measured the learning achievements as the focus is measuring usability and gameplay. Our contribution is to consider elements of usability and gameplay based on the subjects of the research.

\section{Proposal for evaluation of usability and gameplay in educational digital games}

\subsection{The Research Context}

Merging learning, mobility and digital games, this research develops means to assist the school reinforcement of AMO patients and families. Based on this and considering the age group of the subjects, we understand that digital games (Branco and Max, 2011; Barbosa et al., 2014; Barbosa et al., 2011) are more appropriate as means to assist in the needs of the subjects involved in the research. So, elements such as usability and gameplay must be evaluated considering the profile of the subjects of the research. At this moment, the evaluation of the learning process is not our focus. The focus is, however, to evaluate if the game was developed using usability and gameplay efficiency to perform a future learning process in the most advantageous way. Our attention is focused in enhancing the valueadded approach in the game, preparing it to promote learning and motivation (Mayer, 2011).

The 2D educational game called "Corrida Gramatical" will be used as an evaluation object of usability and gameplay by the researched subjects. "Corrida Gramatical" (Barbosa et al., 2014) was developed for tablets, this is a runner type game, with a cartoon-based graphic, where the character is always in motion. The objective of this game is to reinforce Portuguese grammar, one of the school subjects in which Brazilians experience greater difficulty. In the same way, the participants of this research also struggle with Portuguese. This is one of the consequences of the disease as the patients are not able to keep up in school during and after the periods of hospitalization or low immunity. The content was prepared by a Portuguese language teacher. The challenge brought by the game is to control the character to achieve the most stars they can and answer correctly the most 
questions without losing the three lives available. The game also has two types of commands, touch and tilt using the accelerometer, considering the different phases in which the patient undergoing cancer treatment faces so the player can choose the way that best fits to his or her condition. This means that if the person needs to lie down or feel nauseous, it is possible to play using the accelerometer. In a critical phase of the disease, the person may use the commands, which brings more control over the times and spaces in the game graphic. Once the character can "fly" with his wheelchair, the player can dodge obstacles, collect score items, such as small stars, as well as to collect larger stars, which increase points by asking content questions.

\subsection{The research participants}

The subjects of the research are patients aged 10 to 15 years old in oncological treatment who participate in the activities "Learning with Mobility" developed in the context of our research with AMO. As an inclusion criterion, we selected people who were in process of confinement at home due to low immunity. This requirement was established because it is at this stage of the disease that games can help patients to work on elements related to school content since they are away from school. In addition, the developed games must provide usability and gameplay elements for critically ill patients. Considering the inclusion criteria, five patients were selected to participate. Among these five people, three of them accepted to receive the researcher to develop the research. The application of the game occurred in the subjects' house in the afternoon time. First, the researcher called the patients' families and described the activities that would be carried out with the subjects. Then they scheduled the application. At the scheduled date, the researcher went to the residences of all the individuals. The data on the use of the game was compiled and tabulated so that the development team could evaluate it and make subsequent changes in it.

\subsection{The proposed method}

The proposal of usability and gameplay evaluation of an educational game presented here triangulates the data collected from three data collection instruments: nonparticipant observation (Gauch, 2003), SUS questionnaire (SUS, 2018) and semi-structured interview (Gauch, 2003). These elements are included in the instruments used during the game evaluation process.

The instruments organization is presented below: 1) Non-participant observation - in this research strategy, the researcher will remain in contact with the object of the study, but will not be integrated into it, therefore acting as an observer. The researcher assigned the following concepts: Very Good, Good, Sufficient or Insufficient. The researcher, besides assigning the concept, must explain which aspect was determinant for the attribution of the concept in the observed item. The items observed aspects are: 1) ability to handle the tablets, 2) understanding of the game menus, 3) understanding of the purpose of the game, 4) understanding of the game questions, 5) fun provided by the game, 6) competitiveness between patients through the use of the game, 7) satisfaction retention based on the replay of the game, 8) visual attractiveness of the game, 9) understanding of the game feedback, 10) inclination to play again. The objective of this instrument is to identify how subjects play the game, the difficulties of understanding and comprehension of what is requested, the playing time of each subject, the number of points each player scored, and in which way (taking questions or dodging them), and general aspects of gameplay and usability of the game. 2) SUS Questionnaire. This instrument objective is to evaluate usability. The questionnaire type will be the System Usability Scale (SUS). It is a questionnaire composed of 10 items, with 5 options of answers (I completely agree (5) to I completely disagree (1)) using Likert scale. The SUS questionnaire became a standard method for software usability analysis. In this study an adaptation of the questions was 
made, converting items of software use to use of digital games. The items of the questionnaire are the following: 1) The game is difficult to play, 2) The game is easy to play, 3) I would need the help from a technical support to be able to play this game, 4) I understood the rules of the game, 5) I think the game was confusing, 6) I think that most people would learn to play this game quickly, 7) The game crashed or errors occurred, 8) I felt happy playing this game, 9) I had to learn several things before I could continue playing this game, 10) I would like to play this game again. 3) Semi-structured interview. The semi-structured interview may bring other questions and other perspectives in approaching the subject. The interviewer is free to develop the questions in a more comprehensively way. This type of interview also allows the individual understanding of the subject through more specific questions. This technique allows direct contact with the subjects, portraying as many elements as possible in the studied reality. For each item of the interview the researcher takes notes of the answers and can make other inquiries if necessary. The Interview (I) items are the following: 1) Do you usually use tablets? How often? 2) Did you like the "Corrida Gramatical" game experience? 3) Did you like the game theme? 4) Did you like the game colors? 5) Did you have any trouble reading or seeing any information? 6) Did you understand the commands of the game? 7) Did you understand the game menus? 8) Have you ever played other games on tablets? 9) Would you play the game "Corrida Gramatical" again? 10) What would you add to the game? The object of the interview is to identify perceptions regarding to the game rules, motivations to continue playing, difficulties in interacting with content, as well as how they interact with the gameplay of the game.

The proposed usability and gameplay evaluation elements are evaluated based on the triangulation of the three instruments above, considering the subjects of the research. This is the contribution of this work. The proposed usability and gameplay elements are aligned with the theoretical study performed (section 2). Each data collection instrument was triangulated to measured usability and gameplay elements. Table 01 presents the usability elements evaluated, as well as which items in the instruments contributed to the analysis. Table 2 presents the gameplay elements evaluated, as well as which items in the instruments contributed to the analysis.

Table 01 - Usability evaluation elements and their relation to the instruments.

\begin{tabular}{|c|c|}
\hline Usability Element Evaluated & $\begin{array}{l}\text { Valuation item in the instrument: } \\
\text { Interview }(\mathbf{I}) \text {-- Questionnaire }(\mathbf{Q}) \text {-- } \\
\text { Observation }(\mathbf{O})\end{array}$ \\
\hline Consistency and standards & I - 6 and $8 ; \mathrm{Q}-2,4,5$ and $9 ; \mathrm{O}-2,4$ and 9 \\
\hline User control and freedom & $\mathrm{I}-7 ; \mathrm{Q}-5,8$ and $9 ; \mathrm{O}-2$ \\
\hline Visibility of system status; Flexibility and efficiency of use & $\mathrm{I}-6 ; \mathrm{Q}-2,3,7$ and $10 ; \mathrm{O}-1,9$ and 10 \\
\hline $\begin{array}{l}\text { Assistance to users in recognizing, diagnosing and } \\
\text { recovering Wrong actions; Error prevention }\end{array}$ & $\mathrm{I}-6 ; \mathrm{Q}-3,4,8$ and 9 \\
\hline Equivalence between the system and the real world & $\mathrm{I}-3$ and 8 \\
\hline Recognition instead of memorization & $\mathrm{I}-1$ and $8 ; \mathrm{Q}-2,5$ and $10 ; \mathrm{O}-7$ \\
\hline Aesthetics and minimal design & $\mathrm{I}-2$ and $4 ; \mathrm{O}-8$ \\
\hline Help and documentation & $\mathrm{Q}-4,7$ and $10 ; \mathrm{O}-9$ \\
\hline Efficiency & $\mathrm{I}-5 ; \mathrm{Q}-1,4,6,7,8,9,10 ; \mathrm{O}-1,2,4,8,9,10$ \\
\hline Learning & $\mathrm{Q}-4,7$ and $10 ; \mathrm{O}-4,7$ and 10 \\
\hline Flexibility & $\mathrm{I}-7 ; \mathrm{Q}-8$ and $10 ; \mathrm{O}-2$ and 10 \\
\hline Attitude & $\mathrm{Q}-2,6$ and $9 ; \mathrm{O}-9$ and 10 \\
\hline
\end{tabular}

Table 02 - Elements of the gameplay evaluation and its relationship with the instruments.

\begin{tabular}{|l|c|}
\hline \multicolumn{1}{|c|}{ Gameplay rated elemento } & $\begin{array}{c}\text { Valuation item in the instrument: } \\
\text { Interview (I) -- Questionnaire (Q) -- Observation }(\mathbf{O})\end{array}$ \\
\hline Rules & $\mathrm{I}-6 ; \mathrm{Q}-3,6$ and $10 ; \mathrm{O}-3$ \\
\hline Mechanical Engineering & $\mathrm{I}-2 ; \mathrm{Q}-3,6,7$ and $10 ; \mathrm{O}-3,5$ and 9 \\
\hline
\end{tabular}

V. $17 \mathrm{~N}^{\mathrm{o}}$ 3, dezembro, 2019 RENOTE DOI: 


\begin{tabular}{|l|l|}
\hline Goals & $\mathrm{I}-5$ and $6 ; \mathrm{Q}-4$ and $9 ; \mathrm{O}-3,4,7$ and 10 \\
\hline Arena & $\mathrm{I}-3 ; \mathrm{O}-3,8$ and 9 \\
\hline Voluntary & $\mathrm{I}-9 ; \mathrm{Q}-1$ and $9 ; \mathrm{O}-5,9$ and 10 \\
\hline Uncertainty factor & $\mathrm{O}-5,7$ and 10 \\
\hline Gameplay & $\mathrm{Q}-5$ and $10 ; \mathrm{O}-5,8,9$ and 10 \\
\hline Results & $\mathrm{I}-9 ; \mathrm{O}-4,5,6,7$ and 10 \\
\hline Competition & $\mathrm{Q}-9 ; \mathrm{O}-4,5,6$ and 10 \\
\hline Make-believe & $\mathrm{I}-3 ; \mathrm{O}-3,5$ and 8 \\
\hline
\end{tabular}

The research action, from the application of the instruments to the analysis of the game, was developed in 3 stages: 1) Collect Data, 2) Data Analysis and 3) Elaboration of the Game Change Report. The same person (the researcher) led all interviews. In the Evaluation stage, the game, the research project and a brief explanation about the data collection instruments were presented, following up the evaluation procedure. In this stage two phases of application of the game were developed with the target audience. In the Data Analysis, the instruments were tabulated, and the data was triangulated, confronting all the answers of each of the subjects with the elements of usability and gameplay. In the third step, the game was developed, when items referring to the usability and gameplay of the game were identified, and necessary changes in the game was specified.

\section{Case Study - Research Action}

In the first stage, the evaluation, the application of the game and the instruments occurred in the residence of each of the 3 selected subjects, in two different moments, namely: 1) First game application: the researcher explains the research objectives and delivers the tablet with the game "Corrida Gramatical". The subject plays until the two levels available in the game are finished. During this process, the researcher performs the non-participant Observation, supported by the video recording of the player to determine the starting times, score and behavior in relation to the content for further analysis. At the end of the application, the subjects answer the SUS questionnaire. 2) Second application of the game: at this moment the subject plays supported by the gameplay knowledge and by the content. After the game ends, the researcher applies the semi-structured interview. Responses are recorded in audio and used in the data tabulation process when necessary. The data collected from playing the game "Corrida Gramatical" was compiled and tabulated. After that, the elements of usability and gameplay were evaluated from the triangulation of the three instruments, as shown in Tables 1 and 2. Each subject chose their nickname in the research. The elements of gameplay and usability highlighted in each of them refer to those partially covered in the description, together with the reasons observed. Therefore, the other items, when not mentioned, were fully achieved.

\section{Subject 1 - Demi}

Demi was not going to school since the illness treatment started (more than 2 months). After introducing the game, the research project and instruments that would be applied, the researcher gave the tablet to Demi and started the non-participant observation. Her tablet-handling performance was good, she opened the game "Corrida Gramatical" quickly and made a very quick navigation, watching and acting agilely and confidently. However, since she was anxious to start the game, she did not realize that the game had a selection of characters and users, so she played "Start". For her, it was easy to understand the character movements and the game purpose, collecting the small stars to score and the big stars to answer questions. After the application of the game and the non-participant observation, Demi performed the SUS questionnaire, obtaining 97.5 points out of 100 , which is an excellent score. In a second moment, she played the game again and the semistructured interview was applied. Playing quickly and objectively, she proved to have great skills in managing the menus and identifying the game objectives, what is due to her

V. $17 \mathrm{~N}^{\mathrm{o}}$ 3, dezembro, 2019

DOI: RENOTE 
familiarity with her own smartphone and to the fact that she was used to playing games on her device. Demi enjoyed the experience, theme and colors of the game, and did not have problems operating the menu. She would like to play the game "Corrida Gramatical" again because she enjoyed the game and learned from it. She also answered that she would not add anything to it.

In the application of the instruments focused on usability and gameplay for Demi, the following elements were partially achieved: 1) Usability: The equivalence between the system and the real world and the flexibility. In the first element, she did not recognize the scenery of the game "Corrida Gramatical" as a school; and in the second item, she did not realize that she could select other characters and other scenarios. Demi went straight to the game, looking for the start button, then when she was asked about the other scenarios and characters, the user said that she did not identify these options. 2) Gameplay: Rules, Objectives, Arena, and Make-believe. Regarding to rules and goals, first, she did not recognize them, and second, she faced problems controlling the character by using the accelerometer. In the arena and make-believe elements, Demi did not recognize the scenery as a school and did not recognize the opponents as other students.

\section{Subject 2 - Arcanjo}

The second subject identified as Arcanjo. He is going to school but only the days when it is possible. We presented the game, the research project and the instruments, and started the non-participant observation. It was exceptionally easy to him to handle the device, the games and the menus. He browsed all the menus and selection screens before starting the game. On the first few questions, he misread the questions and made some mistakes, but then he read the feedbacks and hit several questions in sequence. Arcanjo seemed to enjoy the game experience. After the end of the game, he filled in and got a score of 92.5 in the SUS questionnaire, which is excellent for the usability test. On the third instrument applied, the semi-structured interview, the answers were very direct and fast. His agility and comfort using the game were due to the prior use of his own tablet, once he told he used to play games twice a day. Arcanjo enjoyed the game "Corrida Gramatical" experience because he could learn and have fun. He also said that he liked the theme of the game because it resembles his school, and that the flashy colors contributed to make him better see the information on the screen. He completed the interview by saying that he would like to play the game again, without adding anything to it, since it was already complete and instructive in his opinion.

In the application of the instruments focused on usability and gameplay for Arcanjo, the following elements were partially achieved: 1) Usability: User control and freedom, Visibility of system status, Flexibility and use efficiency and Flexibility. In the first element this occurred because the user did not recognize the game mode that uses the accelerometer and in the second and third item, it occurred because he did not realize that he could select other characters and other scenarios before starting the game. 3) Gameplay: Gameplay and Competition. In both elements, Arcanjo found the game a bit difficult. He was able to partially control the character, he could not dodge the opponents and the score that he obtained was compromised because he soon hit three opponents. The last two times he played, he managed to better control the character and scored higher than in the previous ones. The researcher stated that the player felt a bit fatigued due to his disease. Therefore, it might have compromised Arcanjo's performance.

\section{Subject 3 - Socrates}

The third student chose Socrates as his nickname. At that time, he had not been able to attend school for more than 2 months. After the researcher presented the project, the main objectives of the game and the instruments, the player proved to be proficient handling the tablet, during the non-participant observation. Besides that, he also had a good 
understanding of the menus and of the main objectives of the game. He read it carefully, but missed all the first questions. Despite this initial problem, Socrates read the feedbacks and succeeded on completing the tasks when they reappeared. His score was 90 points in the SUS questionnaire, which is an excellent score. However, he had more difficulties if compered to Demi's and Archangel's results. In the semi-structured interview, the subject proved to be proficient using the tablet and playing games due to his habit of playing every day, especially on the days he was in the hospital to have his chemotherapy treatment. $\mathrm{He}$ answered that he enjoyed the experience of the "Corrida Gramatical", the theme and the colors, without having had difficulty in seeing the information. He contributed in a different way by responding that he found the time was short, in several occasions, so he could not read and answer the most extensive questions, even though he already had experience with other tablet games.

In the application of the instruments focused on usability and gameplay for Socrates, the following elements were partially achieved: 1) Usability: Efficacy and Learning. In the first element it happened because the user thought he had a short time to read some questions and answers of the game and in the second item, the user missed some of the most extensive questions in the first time he played, what leads us to believe that the time for questions and answers were insufficient for their reading speed. 2) Gameplay: The application of the instruments to Socrates achieved most of the elements. The only ones which were partially achieved are Rules and Mechanics. In both elements, because the player found the game difficult. However, he did not have problems operating the character. The only problem he had was in answering the questions correctly. He missed many questions, and the researcher believes that this is the reason why he found the game difficult.

\section{Results and Conclusion}

Based on the results of the players in relation to the gameplay, we believe that the applied instruments contributed to the identification of the characteristics that should be changed in the game "Corrida Gramatical", and that it also can be useful in the development of other games in the context of the research. An important piece of information regarding to the usability issue is that all the participants already were proficient using tablets and smartphones, both to play and surf the internet, what made it easier for them to adapt to the game.

Based on the Data Analysis, necessary changes in the development of the game "Corrida Gramatical" were identified, producing Report of Changes for the game, namely: 1) Menus: In the initial menu, a new button with game instructions is proposed, which would show the two game modes. In the menu of scene selection and character, it is proposed a different operation: The play button must be disabled and no scenario and character must be selected, what will make the player select the two items to then release the play button to start the game. In the scenario selection menu, the suggestion is to name each scenario, giving name to the school. 2) Before starting the game: As soon as the Play button is pressed at the scene and character selection menu, the game environment is shown as a tutorial, with highlights to demonstrate the stars that must be picked up, the opponents that should be avoided, the lives available, and finally, the two ways to interact with the character by touching the screen or tilting the device using the accelerometer. 3) During gameplay: Adding more reading time for longer questions, 45 seconds. Adding lives to catch during the match so the player can go further in the game. Adding a continue button on the feedback of the wrong answers.

Based on the analysis of the application with the players of the research, one can notice that the instrument proposed in this work to analyze the usability and gameplay, having as a study case the game "Corrida Gramatical" was effective and reached the 
proposed objectives. It not only was effective in identifying problems related to gameplay that could not be previously observed by the development team.

The elaboration of this work used a modification from the point of view of professional practices in classroom and game development. The application of the instruments and tabulation of the results shows that the gameplay and the usability provided by the game "Corrida Gramatical" are satisfactory. However, the results also highlight the necessity of adjustments in elements of both gameplay and usability, what can be observed in the proposed changes to the game. In future researches, we intend to select a larger group of subjects to better identify other elements of usability and gameplay, what may evidence the need for adjustments in certain elements of both gameplay and usability, according to the evaluation analysis performed. Considering the data collection instruments, specially the non-participant observation and the semi-structured interview, results do not show problems regarding to the school topics. For this reason, we understand that students can comprehend the topics by using the game.

Finally, the study application showed that the test with the subjects and the examination of the players interaction with the game, was determinant for the success of the study. Hence, we propose that games in the development phase can test the public since it enables the identification of how people interact with the game and with the predictable gameplay, even in the development phases. The identification and correction of issues can be helpful for the developers and it can also positively affect the result of the final product. The dialogue with the users and the recognition of the ways they deal with the game, as well as the identification of their game preferences, were important in determining the conclusion of this study. The results show that the evaluation of usability and gameplay with the proposed method is possible and the methodology is adequate to support the development of mobile educational games considering the research scenario. As an inclusion criterion of participants, children and teenager in process of dropping out of school and incarceration at home, due to low immunity system issues were chosen. Given this points, five patients were selected to participate, of which three accepted to receive the researcher to apply the research. For future studies, we intend to change the inclusion criteria to select a larger group of patients and reaffirm the effectiveness of the proposed method.

\section{Acknowledgment}

We would like to thank Feevale University and Unisinos for embracing this research. The authors are also grateful to $\mathrm{CNPq}$ (National Council for Scientific and Technological Development) by their support in the development of this research.

\section{References}

BARBOSA, D. N. F, BASSANI, P. B. S., MOSSMANN, J. B., SCHNEIDER, G. T., REATEGUI, E., BRANCO, M. A. A., MEYRER, L. S., NUNES, M. Mobile Learning and Games: experiences with mobile games development for children and teenagers undergoing oncological treatment; Lecture Notes in Computer Science, 8495,153-164, 2014.

BARBOSA, J. L. V. ; HAHN, RODRIGO ; BARBOSA, D. N. F.; SACCOL, A. C. S. Z. 'A Ubiquitous Learning Model Focused on Learner Integration'. International Journal of Learning Technology, v. 6, p. 62-83, 2011.

BRANCO, M., MAX, C. LUDEMAS. Lógica da Sedução nos Games. In: X Simpósio de Games e Entretenimento, Salvador. Ludemas. 2011.

CARVALHO, M.; BELLOTTI, F.; BERTA, R.; DE GLORIA, A. ISLAS SEDANO, C.; HAUGE, J. HU, J.; RAUTERBERG, M. An activity theory-based model for serious games analysis and conceptual design. Computers \& Education. 87, 2015; 166-. 10.1016/j.compedu.2015.03.023. 
CYBIS, W. Ergonomia e Usabilidade : conhecimentos, métodos e aplicações / Walter Cybis, Adriana Holtz Betiol, Richard Faust. 2 ed. São Paulo : Novatec Editora, 2010.

DIAS, LUCAS P. S. ; BARBOSA, JORGE L. V.; VIANNA, HENRIQUE D. Gamification and Serious Games in Depression Care: a Systematic Mapping Study. Telematics and Informatics., v. 1, p. 1-20, 2017.

DINIZ, A. D. S.; STRADA, F.; BOTTINO, A. Investigating the Design and Evaluation of Educational Games Under the Perspective of Player Experience'. 218-227; 2017; 10.1007/978-3-319-71940-5_20.

GAUCH, H. G., JR. Scientific Method in Practice, Cambridge University Press, ISBN 0521-01708-4 435 pages, 2003.

MAYER, R. E. Multimedia learning and games. In Tobias \& Fletcher (Eds.), Computer games and instruction (pp. 281, 305). Charlotte, NC: Information Age. 2011.

MORENO-GER, P.; TORRENTE, J.; HSIEH, Y. G.; LESTER, W. T. Usability testing for serious games: making informed design decisions with user data. Adv. in Hum.-Comp. Int. Article 4, January, 1 pages. 2012, DOI=http://dx.doi.org/10.1155/2012/369637

MOSSMANN, J. ET AL. Project and Evaluation of VR-MED, a Domain Specific Language for serious games in Family Medicine Teaching. Computer Software and Applications Conference (COMPSAC), 2016 IEEE 40th Annual. IEEE, p. 663-667, 2016.

NIELSEN, J. Ten Usability Heuristics. 1995. Disponível em $<$ http://www.nngroup.com/articles/ten-usability-heuristics/>. Acesso em: 01 out. 2017.

PREECE, J. et al. A Guide to Usability: human factors in computing. Reino Unido: Addison Wesley, 144p, 1993.

RAESSENS, J. The gaming dispositif. An analysis of serious games from a humanities perspective. In: Ritterfeld, U.; Cody, M., et al (Eds.). Serious games. Mechanisms and effects. New York: Routledge, p.486-512, 2009

RIBEIRO, G. L. H.; FENANDES, N. M. P.; GARONE, P. M. C. O design e a jogabilidade. Artigo SBGames, São Paulo, 2013 Disponível em: < http://www.sbgames.org/sbgames2013/proceedings/artedesign/01-dt-short.pdf > Acesso em: 10 jan. 2018.

RITTERFFELD, U.; CODY, M.; VORDERER, P. (Eds.) Serious Games: Mechanisms and effects. London: Routledge. 2009.

SANTOS, H. V. A. A importância das regras e do gameplay no envolvimento do jogador de vídeo game. Tese de Doutorado. USP, Escola de Comunicação e Artes. 2010.

SHACKEL, B. Ergonomics in design for usability. In: HCI 86 Conference on People and Computer. New York: Cambridge University Press, 1986.

SHACKEL, B. Usability - Context, framework, definition, design and evaluation. Interact. Comput. 21, 5-6, 339-346, 2009, DOI=http://dx.doi.org/10.1016/j.intcom.2009.04.007

SUS questionnaire. Available at: https://measuringu.com/sus/. 2018.

VIANNA, HENRIQUE D. ; BARBOSA, JORGE L. V. Search of Computer-aided Social Support in Non-communicable Diseases Care. Telematics and Informatics, v. 1, p. 1-10, 2017. 